CHAPTER 13

WILLIAM BRADLEY

\title{
RISK, MEDIA AND JAPANESE YOUNG PEOPLE
}

\section{INTRODUCTION}

Theories of risk in society have defined and extrapolated on risk in multiple ways depending on the object of study and types of claims made by the author. Zinn (2008b) lists six main traditions, including risk society, cultural turn, and governmentality. One of the central problems that more recent work on risk has focused on is how risk varies according to the fabric of particular everyday lives in particular societies and under various types of social arrangements (Tulloch and Lupton, 2003; Tulloch, 2004). In this chapter I explore this problem of risk theory by looking at the views Japanese young people have about risk in Japanese society.

In risk society theory, Ulrich Beck $(1992 ; 1999)$ made his characteristic claim that risk enters as a second modernity. Yet, while the totalizing aspect of transition in risk society theory to a second or reflexive modernity has been treated by many sociologists with skepticism, risk society theorists have been able to claim, at least cautiously, that some notable change indeed has occurred globally with the rise of the possibility of catastrophic risk, symbolized by nuclear accidents and contamination, the worldwide transports of toxic wastes, and the rapid spread of diseases like AIDS, SARS, BSE, avian flu and other new viral infections that are spread easily by the globalization of food, migration of people and changes in environment due to human activities. In World Risk Society, for example, Beck (1999) states that a "key question is how that model [of reflexive modernization] relates to the different modernities in other parts of the world" (p. 2, italics in original). However, with few exceptions, for example a contribution to a special issue in Korea Journal (Beck, 1998), he has had relatively little to say specifically about risk society in other parts of the world, a gap nonetheless filled by others with ethnographic perspectives drawn from a multiple set of sources (Caplan: 2000). Although Beck's focus has often been Euro- or even German-centric, he has written that the rejection of "radical otherness" is "an important standpoint in revising the evolutionary bias of much of the Western social sciences to this day." A defining aspect of risk developed in the context of analysis of South Korea, for example, will certainly contribute to understanding the global interconnectedness of risk as well as inform risk analysis and theorization in those parts of the world seen by many as prime initiators of risk and risk society, namely Western Europe

S. Bialostok, R.L. Whitman and W.S. Bradley (Eds.), Education and the Risk Society:

Theories, Discourse and Risk Identities in Education Contexts, 265-278.

(C) 2012 Sense Publishers. All rights reserved. 


\section{WILLIAM BRADLEY}

and North America. There is a necessity, in short, "not only to include nonWestern societies into any analysis of the challenges of the world risk society but also to examine the specificities of the local refractions of the global-local risks in these societies" (Beck, 1998, pp. 200-201).

Many scholars in various disciplines have struggled with the question of comparing modern Japan with other post-industrial societies (Grew:2002) as Japan often serves as a lense through which the basis for alternative modernity hypotheses can be weighed with respect to the contrasting variables in questions of universalism versus particularity. Claims that Japan is not a risk society (Clammer:2002) or Japanese does not have the word risk (Douglas: 1992), except for the katakana form of the English word in Japanese, 'risiku,' nothwithstanding, my claim in this chapter is that Japan is not only a country in which risk is now a commonplace, it is one in which ordinary Japanese have increasingly recognized risk in reflections on their daily lives over the past decade. ${ }^{1}$ The research described below was carried out in this time frame but certainly risk has gained a new significance in Japanese society due to the nuclear contamination in Fukushima that followed the gigantic earthquake and tsunami of March 11, 2011.

Whenever a researcher sets out to shed light on the "Japanese question," to borrow Kenneth Pyle's (1996) phrase in a slightly differing context, that considers how Japan relates to the rest of the world on issues of social change such as posited by risk society theory (Adam, Beck and Van Loon, 2000; Beck, 1992; 1999, 2000), we need to acknowledge some of this ambiguity that has bedeviled analysis of Japan as a modern polity, but one that has often been seen from the outside as a prototypical Other, modern but also traditional, hyper-capitalist but at the same time hierarchical and group-oriented. Here I can only allude to long debates regarding social science research on Japan as influenced either by Orientalism or Ninhonjin-ron (literally theories of the Japanese), drawing attention to the way that Japan and the Japanese have been portrayed, and in many cases portray their own society, as unique. I attempt in this chapter to show a local instantiation of risk, that is, in Japanese society in the past decade, while at the same time linking it to wider universalist discussions of the global risk in society.

\section{RISK AS A CONCEPTUAL TOOL}

The proliferation of risk as a concept in social science necessitates some introductory remarks in order for the purpose of research to become more salient. It is impossible to do justice to the widest range of work utilizing the sociological concept(s) of risk in a chapter of this length (since Beck's original work in English was published more than 20 years ago and has been followed by numerous critiques; e.g. see Mythen, 2004) and still provide an overview of a particular research project in educational settings and issues related to risk as I will do here. However, I highlight at least some of the important theoretical starting points for a study of risk consciousness among Japanese 18 to 20 year olds.

Beck's lack of empirical substantiation in proposing a global risk society does not invalidate the possibility of fin ding fits between this larger risk society theory and 
local non-Western contexts. However we need to look to other sources to see how this would be the case, if indeed it is. A number of the chapters in the anthropologically oriented book Risk Revisited (Caplan, 2000) do, in fact, theorize risk in local non-Western contexts and propose understandings of risk as well as challenge risk theory more generally. Such understandings contrast to the notion that. risk being discovered in the West in a global narrative of us and them which, while suggesting certain relations of power, through economy, technology, and industrial export (prime originators of global risk) are not well explicated, if at all. "That risk should be elevated to the status of a defining feature of the age suggests ... the prospect that as the West finds it more difficult to displace its crises onto others, it begins to adopt the posture of the beleaguered, out of control in a manner previously assigned to inhabitants of the periphery" (Nugent, 2000, p. 246).

In a similar manner, Vera-Sanso (2000), argues that the focus on risk as somehow a successor to material needs (argued by Beck to be no longer of prime importance in the affluent West) is off target. Risk in India is best perceived as "a concern for social status and maintaining social order" and should be oriented to a political explanation which investigates "the way dominant definitions of risk set moral codes which frame disciplinary regimes, constrain action and set the terms of debate in which people engage both to enforce and resist the impact of such definitions" (pp. 128-9).

Seen in the context of Japanese society, these two analyses suggest that the offsetting of internal crises onto more vulnerable parts of society (i.e. the poor and young) and the framing of problems in terms of dominant codes and discourses of the narratives of changing society are universalizing approaches to risk in the $21^{\text {st }}$ century. The Japanese government has customarily cloaked its international political agenda in the shadow of its half century long military and political alliance with the U.S., and Japanese citizens have developed highly individualized consumer lifestyles (automobility, fast food, hip hop and pop music, and Hollywood movies, etc.) that are generally agreed by many Japanese to be a benign (or at least inevitable) aspect of globalization. In his 1994 acceptance speech for the Nobel Prize in literature, titled "Ambiguous Japan and Myself" [Aimai na Nihon to Watashi], Oe Kenzaburo reiterated the enduring problem of a political (as well as social and cultural) identity for Japan, as part of Asia but looking toward the West, particularly the U.S (Oe, 1994). ${ }^{2}$

On the one hand the "uncertainty of self," (Tamamoto, 1999) that has been at the root of the identity of ordinary Japanese in modernity, and has been expressed by many commentators, particularly since the lost decade of the 1990s and afterwards (Miyazaki, 2010; see also Brinton, 2010 for a discussion of the "lost generation"), has become more attenuated over time, while on the other hand, successive waves of neoliberal government strategies have contributed to objectifying the sense of unease of all but the most financially secure of Japanese citizens. It is not simply a question that risk society has "come" to Japan as it has to other countries of East Asia, like China (Thiers, 2004), along with the realization on the part of most ordinary citizens that their elected government is unable and some cases deliberately declining to address the problem of increased 


\section{WILLIAM BRADLEY}

risk being offloaded from the realm of central bureaucratic management into the lives of individuals. Various domains of public policy have been increasingly subjected to management that obviously manipulates risk in favor of social preferences biased in favor of neoliberal capitalism and privatization. This can be clearly seen in educational policy where an earlier narrative of Japan as a rather successful global leader is increasingly submerged by Japan as a nation at risk (Takayama, 2007; Willis, et al, 2008).

Some earlier theorizations about risk in Japan had suggested that it is nearly non-existent as an indigenous concept. Douglas (1992:14) argued, for example, that because no word exists in Japanese, and only recently had Japanese used the katakana form of risk, risiku, that Japanese have been living, and perceived themselves as living, in a fundamentally risk-averse society. The result, based on her linkage of risk to political mobilization, is a claim that societal problems which involve phenomena based on risk perceptions and definitions in other societies can be solved in a much more straightforward manner in Japan, i.e., relying on the bureaucracy to sort things out, relegate blame, and impose its will. Clammer (2001:40) had argued in a similar manner that Japan has been "characterized by low levels of individualization," which, combined with the strong power of bureaucracies, means that solutions to or mobilizations around problems that might otherwise be labeled and politicized as risk do not often make their way into the public arena in Japan.

I argue, however, that in contradistinction to such claims, there has been a growing discourse surrounding risk as mediated through the mass media with focus on issues such as nuclear accidents, BSE, SARS and other technoscience problems. A problem to be resolved much less easily, however, is the degree to which such a consciousness leads to concrete action and change.

While risk phenomena certainly have a real component to them, in that they are capable of causing individuals great harm, they also depend for their power on the amplification that they receive in the media. The question of how media mediate risk is one that has been undertheorized in Beck's work, as critiqued by a range of scholarship (Boyne, 2003; Mythen, 2004, Van Loon, 2002). As pointed out by many of these critiques, media portrayal of risk is not as straightforward as might first appear. Mythen's (2004) discussion, in particular, of media reliance on government and institutionalized scientific sources, as well as the political economy of media itself, is important in illustrating the difficulties of bringing popular attention to a particular issue which in turn helps to shape risk perception. Van Loon (2002) makes the strongest case for the virtual mediation of images of risk, which he calls a "crisis of actualization" (p. 155) noting that what gains attention is only "panic ecology" (p. 163). Boyne uses the phrase "emotional spectacularization" (p. 40) to describe the way media capitalizes on the "tension [which] is between analysing risk and creating an appetite for its images" (p. 35).

Media in Japan, as in many other countries, is dependent on the short attention spans of audiences. From my many years of teaching, it has long surprised me how few Japanese university students profess to reading a newspaper, watching the news on television, or accessing a news site through the internet. This certainly has 
a bearing on how risk can and should be defined in order to operationalize research on perceptions about it. While university students were a target of opportunity, I also hypothesized that, among the larger population of Japanese youth, they would tend to have higher interest in issues defined as risk. In the next section, I briefly delineate several cases prior to the events of March 11, 2011, that show risk in Japan and how media interacted with them.

\section{Mad Cow Risk}

In September 2001, the first case of BSE (bovine spongiform encephalopathy or mad cow disease) was announced after a cow tested positive. The second and third cases were confirmed in November and December in different regions of Japan, while the fourth and fifth cases were confirmed in May of 2002. By the fall of 2004, the number of confirmed cases in Japan had risen to 15 . The story was then complicated by the first discovery in 2003 of BSE in the U.S., a major exporter of beef to Japan, subsequently leading to the ban of imports of U.S. beef. Shortly before the remaining stocks of cheap American beef in Japan were consumed, TV cameras showed long lines of customers queuing in order to eat the last dishes of gyudon, a dish made from beef and rice, at a low-cost fast food chain. While many consumers expressed anxiety over the quality of beef, many others wanted to get their last beef bowl before the ban went into effect. The ban was rescinded in 2006 at which time more than thirty cases had been identified, and except for the occasional flap over imports from the U.S. with banned parts (e.g. bovine spinal columns) American beef sales have resumed in the Japanese market.

\section{Nuclear Radiation Risk}

Other kinds of catastrophic risks are also not new to Japan; however the exposure of the failure status quo management strategies makes them good examples of how risk has increasingly been exceeding its natural borders. For example, in September 1999, Japan experienced its heretofore worst ever nuclear accident, in which 69 people were exposed to high levels of radiation, two workers were killed, and another was seriously injured. This was just one of a series of similar types of accidents and fires that have occurred at nuclear processing facilities and plants around Japan since its introduction into Japan in the 1980s. What was different in this case was the discovery of a bootleg manual that instructed the workers how to make nuclear fuels by mixing uranium oxide with nitric acid using a stainless steel container instead of the usual mixing apparatus. Apparently this method was a way to cheapen the process and had been in use for several years. In the summer of 2004, a new accident at a nuclear facility in Fukui claimed the lives of four workers as pipes which had badly deteriorated after 28 years of use exploded with boiling water. Once again the ritualized scene of government officials bowing in public and claiming responsibility was broadcast on Japanese TV, but it seems clear that fewer and fewer Japanese people find such public displays trustworthy indicators of institutional responsibility. 


\section{WILLIAM BRADLEY}

In the months following the nuclear disasters in Fukushima of 2011, due to flooding from the March 11 tsunami which overwhelmed the cooling capacity of multiple reactors and left spent nuclear materials exposed for periods long enough to cause widespread contamination in the surrounding areas, many Japanese came to the realization that more reliable sources of news were available over the internet and through foreign satellite channels. Lively discussions and activism have resulted from the consciousness that risk cannot be properly left to government, bureaucratic and mainstream media to define and dictate. The results of these developments are likely to have a great impact on Japanese society for many years to come.

Research that investigates the consciousness of risk in Japan must be able to look at two seemingly contradictory dimensions. First, a normative emphasis on risk which has been relatively muted and constrained by reliance on strong administrative political mechanisms, symbolized by powerful government ministries (e.g. the Ministry of Education, Science and Technology or Monbukagakushou). And second, a growing emphasis on exposure of and to risk, related in the media, particularly new media, that portrays the government and its bureaucrats, and corporate representatives, as jeopardizing public health and welfare, even to the point of nearly deliberate indifference to public safety, as the multiple cases above illustrate.

\section{JAPANESE YOUTH AND THE PERCEPTION OF RISK}

This research starts from the premise that risk is indeed an operative concept in the consciousness of young people in Japan. Japanese youth embrace risk more than did an earlier generation and they also have knowledge about some of the phenomena that I defined as risk in the section above, such as BSE and nuclear energy, as well as SARS, AIDS, the loss of secure employment opportunities, and so on. While these phenomena have real effects on ordinary individuals, the degree to which they become objects of concern depends on multiple factors such as crisis coverage in media and other forms of spectacularization.

The origin of this project was a desire to complement work that I did several years earlier interviewing university teachers of English about their conceptions and beliefs regarding computer use. I wanted to focus on how risk is perceived by young people in Japan partly because, in contrast to the claim that risk aversion is the dominant relation to risk in Japanese society, I had seen many examples of Japanese youth embracing risk (Baker and Simon: 2002) and partly because I wanted to compensate an earlier bias in my study of technology and risk on the agents of change (i.e. the teachers) vs. the objects of that change (i.e., the students).

What I hadn't envisioned as this research commenced was that in choosing to emphasize risk in my teaching of several classes of sophomore English reading and writing I was also opening up a possibility for creating alternative responses to the effects of risk in society. While the full implications and possibilities of such responses are not described in this paper, over the years I have worked at integrating elements of critical media literacy (Semali: 2000), based on 
understanding risk and risk society into my classes. Such an emphasis on risk provides students a way of bringing together the disparate phenomena that they read about in the news such as SARS, BSE and mad cow disease, chicken flu, nuclear energy and weapons of mass destruction, genetically modified organisms and biotechnology, cloning and so on. Focus on risk also pinpoints the different modes of knowledge that have been identified as essential for a better understanding of risk: 1) Everyday experience, 2) Science-driven scenarios and 3) Collective narratives, which are increasingly media-driven (Boholm, 2002:173).

The problem of media is one that I wanted to highlight in this research, as media serves both to inform ordinary people of risk but also to amplify and in many cases exaggerate risk, especially certain aspects which can be deemed as falling within normative frames of thinking. While there is no easy solution to education focused on critical media literacy because education must simultaneously utilize and critique the viewpoints presented in mainstream (and hence powerful) media, the first step must necessarily include raising awareness, one of the goals of this research..

In Risk, Environment and Society, Strydom (2002) advances an argument for a cognitive sociology and, drawing on Habermas, proposes a "discursive democratic dispensation" as a vital component for addressing both intentional and unintentional societal risks brought forth by technoscience. A cognitive approach calls attention to public communication and discourse "to critically puncture across the board illusionary projections" (p. 166) of scientific knowledge cloaked in certainty, and policy and administrative measures that veer out of control in so many democratic and technologically advanced societies.

Such a project "compel[s] social scientists to give more focused attention to modes of perception, modes of framing, cognitive structures, and collective processing of cultural models of reality" (p. 152). This focus is in direct response to the emergence of what Strydom calls the "experimenting society," in which hypotheses, experiments, risks and so on are no longer confined to the laboratory but have come to be "motivated and impelled by curiosity, power, wealth, commodification, privilege and ... experimentally implemented in society as laboratory yet in an arrogant manner deriving from its absolutist core of state power structure... [government] insists... is self-contained and [it is] not responsible for any social consequences" (p. 104).

Underlying this research described below is a focus on risk that should aim to explore 1) the cognitive structures groups of people (e.g., teachers and students) use to frame risk; 2) how they come to modify their views through knowledge, interest, and education; and 3) how media can be both analyzed and utilized for deconstructing and reconstructing understandings of risk.

\section{RESEARCHING RISK CONSCIOUSNESS AMONG JAPANESE UNIVERSITY YOUTH}

Japanese universities have in the past decade discovered new sources of risk to their own futures. As in higher education systems in most countries around the world, there has been a steady growth in the percentages of young people who 


\section{WILLIAM BRADLEY}

attend some form of tertiary education. In this respect, Japan is no exception as the percentage of 18 -year-olds entering higher education has increased from roughly $38 \%$ in 1990 to currently around $50 \%$. However as the birth rate is one of the lowest in the world, the overall numbers of students have been falling for some years now and will continue to drop for years to come. University faculty are tasked with goals of preparing for the future, which includes making the university more attractive and useful to the students in multiple ways. Successful employment statistics of graduates are used to match and compare faculties and universities as a whole. Universities are encouraged to push students to look for permanent employment as opposed to casual employment, which has been increasing as a proportion of overall employment in Japan year by year.

Given this background in Japanese undergraduate university education, I designed the research in the summer of 2003 (undertaken in the winter of 2003-04) as a combination of questionnaires and semi-structured interviews (288 and 10 respectively). The sites were six different universities, two of which I taught in at the time (and still do), and four others in which I was able to ask colleagues to let me join their classes to conduct the research in the course of approximately half (45-50 minutes) of a normal 90-minute class period. Two of the universities were public, four were private, two located in Kanto (which, including Tokyo, is the largest metropolitan area in Japan), three in Kansai (the second largest metropolitan area which includes Kobe, Osaka and Kyoto), and one in a smaller city between these two regions. The two public universities were both medical universities, while the private university students were all in various faculties of liberal arts. The size of the samples varies greatly from one institution to the next with normal classes in the medical universities being approximately 50 students and the smallest of the private university samples being 16 students in a class. All of the classes were English classes, so the research was done entirely in English, unless students asked for translation of terms, such as BSE or nuclear energy, which information they were given individually.

The research was introduced with a short article from an English newspaper in the summer of 2003 that described the damage to the Taiwanese economy from the decline of tourists due to the outbreak of SARS. Students were given some leading questions to help them understand how hotel owners suddenly found themselves losing money due to the spread of a new disease and mass media amplification of the risks of contact. They were also asked to think about who might potentially profit from the risk of SARS (facial mask makers, scientific researchers and pharmaceutical companies testing new vaccines, etc.) to suggest that risk is not simply about damage, potential and actualized, but also opportunity.

The questionnaire that followed consisted of four factual questions (gender, age, how often the respondent read the news, and population of city/town of residence), 24 questions on a 4-point scale regarding knowledge and opinions of risks, and four open-ended comment questions on risk. In addition to the questionnaires, ten students were interviewed (tape-recorded and transcribed) and asked about risk in a semi-structured interview format that averaged about 15-20 minutes each. 


\section{Responses}

Of a total of 288 respondents, 176 (or 61\%) said that they read the news every day or once every two or three days. Sixty-three (21\%) said they read the news less than once a week.

Issues which students knew the most about were in the following order (including both know a lot and know something about): global warming (94\%), AIDS (90\%), mad cow disease (83\%), the War on Terrorism (77\%), SARS (69\%), nuclear energy (66\%), genetically modified food (62\%), and computer viruses (38\%).

Eighty-four percent of the respondents claimed to be either interested a lot or some in national and international news. This finding taken together with the attribution that $61 \%$ of the students read the news at least several times a week was greater than I had expected. However, in answer to the question of whether they talk about the news with their friends, only $35 \%$ responded a lot or some, $46 \%$ responded not very much and $18 \%$ responded not at all. This indicates that these Japanese young people have interest in the news but view it from a distance or at least don't exchange opinions about it with friends. More optimistically, however, a full $97 \%$ agreed strongly or agreed that students should learn about national and international news. Those interested in politics and the economy a lot or some accounted for $49 \%$ while those interested in society and social changes accounted for slightly more at $62 \%$.

In respect to three issues, food safety, mad cow disease, and nuclear energy, which I decided to highlight further by asking questions about students' trust in experts, nuclear energy fared the worst with $61 \%$ either worried or distrusting of the government, while $47 \%$ and $29 \%$ had the same to say about food safety and eating beef respectively.

In relation to personal risk-taking, $66 \%$ claimed that they only occasionally take risks or not at all. On the other hand when asked about extreme sports, such as parachuting and bungee jumping, $41 \%$ said they would like to try them and another $40 \%$ said they were OK although they didn't want to try them personally. We can surmise that risk-taking can be defined in many ways so results such as these make it hard to pinpoint the degree of risk that individuals will accept. As a general rule, however, it seems that opportunistic risk-taking within a general comportment of not taking too many risks is the norm for these Japanese youth. For more specific information we need to turn to some of the comments in interviews and on the open-ended questions.

In the interviews, one of the most striking results was the statement of a majority that they are interested in risk but their friends are not. One female student responded to the question of risk-taking in the following manner. "I take them. I don't want to all the time, but if I take a risk, I can learn something from the risk." But she claimed that many of her friends "don't like adventures." Another male student said that, unlike himself, "I think that Japanese people only care about themselves and are not interested in social issues." Another male student stated, "I think the Japanese teenagers don't really think about risk, there's a war in Iraq so that made teenagers recognize the word risk. It might happen in Japan too. People are starting to understand." Finally a female commented, "personally I'm 


\section{WILLIAM BRADLEY}

interested in that but many friends around me are not interested in international issues of Japanese government's actions... it is not clear what kind of problem we will have in future. Japanese government doesn't open the information of our society in future ...government doesn't give me the information I want."

Written statements in the open-ended questions were also collated and coded. In general most of these comments were positive about the importance of understanding risk. This makes intuitive sense because if one were not interested, it is unlikely that he or she would bother to write a comment after already filling in the answers to previous questions. There was some disagreement as to whether most young people were not interested, or had interest but no knowledge, or knew more than they actually said but wrote "not much" knowledge because of the difficulty of getting reliable information. Here again, an aspect of what kind of knowledge of risk "counts" is an open question. Many respondents seem to suggest that they have interest and knowledge while others don't, or don't have enough, or don't know that they know.

Another finding worth noting was the mention of the Iraq war as a trigger for interest in risk among some young people. However, there was also one respondent who claimed that he/she had tried to get more people interested in the impending war without success.

Finally, strong opinions were expressed that the government was not giving people reliable and useful information. "Risks are covered by Japanese government," as one respondent put it. People are not as easily satisfied by the admission of failure on the part of government bureaucrats accompanied by a public apology including bowing for the cameras. While this observation only scratches the surface with regard to the problem of mediatization of risk governance, it is clear that media are often in the ambivalent position of being able to inform about risk but are also stuck on fragile and assailable positions for not providing enough background for complex analysis (before moving to the next crisis') and allowing only an over-simplified rehearsal of contradictory aspects of social problems to be symbolically performed with little real resolution as to what could/should be done to prevent recurrent instantiations of similar cases.

\section{CONCLUSION}

Most recent work on risk theory (Tulloch 2008; Zinn, 2008a and b) has argued that melding of variations of theories of risk is possible as long as careful attention is paid to the localized context and differences of class and status of subjects who are being studied. While it is clear that Japanese young people have some strong understandings of risk, risk-taking, and risk in society, it is also the case that further research would be necessary to explore why they adopt rather fatalistic viewpoints towards the problems of knowledge of risk in Japanese society. A governmental approach would suggest that they are strongly convinced of the power of media to control ordinary people (particularly those other than themselves) while maintaining that they are able to pierce the veil of consciousness regarding the mystification of real and perceived risks. On the 
other hand a cultural approach would acknowledge that the researcher empowered students to talk about risk claims as knowledgeable subjects in an arena in which knowledge is at least of nominal importance. University students are certainly likely to have different views of risk than 18-year-old graduates of high school who are doing industrial work or part-time jobs. While individual responses to changing employment risk and uncertainty are seen by many young people as a matter of personal volition, their choices are greatly structured by class considerations or "risk divides," insecurity for many, tradable skills for the lucky and privileged few (Allen and Henry, 1997; Ekinsmyth, 1999; Evans, et. al, 2001; Furlong and Cartmel, 2007).

More generally, however, at least two divergent scenarios are possible to picture based on the results in this research. One is that risk becomes further normalized through media representation as do-it-yourself responses to one crisis following another. Lash (2002) writes about this as the network society "re-stabilizes the risks of Beck's (1992) risk society partly by calculatingly colonizing - through for example futures markets - the future" (p. 127). He points to the possibility for ordinary citizens to become "arbitrageurs" of risk, personally accepting those they feel comfortable with and can profit from/with while rejecting those that they fear or dislike. This seemed to be partly indicated by some of the results of this research in which many students saw themselves as interested in risk in contrast to other students around them. Such a relation to risk most closely resembles what Crook (1999) calls a "neo-liberal risk management regime," one in which management is largely dependent on "self-regulating capacities of individuals." As such, the "neo-liberal risk management constantly threatens to de-legitimize itself because it delivers the risk without the management" (p. 181).

The second scenario is that through risk consciousness, young people in Japan would become more interested in social issues, advocacy, and change. This would correspond to the hope of analysts including Strydom (2002) who argues that our realization that we now live in experimenting societies can be the impetus to new social and political formations. But in order for that to happen, a much deeper questioning of the link between capitalism and technoscience needs to take place, one in which the entrepreneurial fixes to risk are challenged as "a new form of class conflict." While there was cursory evidence among the university students I researched of such consciousness developing, the events of the past year and ongoing problems of nuclear contamination suggest that a large portion of Japanese people are ready to challenge the normative understandings of risk presented by the nuclear industry scientists and pro-nuclear politicians. The relation between risk understandings generated by ordinary young people, as reported in the media, and media which can be used to further understanding of risk (and here it is important to include new media) is one that will be of great importance as Japanese try to understand the damages that have been afflicted on the northeast region of the country, due to the March 11 earthquake and its aftermath, and what significance these understandings have for building a more open, transparent and responsive political system that addresses the many risks that Japan faces in the future. 


\section{WILLIAM BRADLEY}

The strong interest in risk communication expressed by many of the students in this research attests to the lively possibilities for future teaching and research utilizing risk(s) as thematic content. In the longer term, education about risk both as a curricular theme and content (Quicke, 2001) and about educational restructuring (Robertson, 1999) does offer the possibility of challenging neo-liberal self-destructive policies toward the environment and individualized consumptive lifestyles that are ascendant in many societies including Japan, and have led to overreliance on technoscience as the convenient supplier of solutions to difficult problems related to energy, environment, and sustainable lifestyles.

\section{ACKNOWLEDGMENT}

This is a substantially revised version of a paper originally presented at multiple conferences and based on research published previously in Bradley (2005).

\section{ENDNOTES}

1 Katakana is a Japanese syllabary that is used to transcribe and indigenize foreign words into Japanese. While there is only anecdotal evidence to my knowledge, one the earliest frequent uses of risiku appears to have been by doctors with their patients, explaining operations and other medical treatment options.

2 Oe (2011) has recently reiterated and elaborated on the notion of Japan's modern ambiguity as a pacifist nation sheltered under the American nuclear umbrella and subject to three tragedies and loss of life related to 1) nuclear weapons, 2) testing, and 3) energy, namely the 1945 atomic bombings, the 1954 inadvertent radiation of Japanese fishermen in the South Pacific, due to U.S. nuclear testing at the Bikini Atoll and nuclear radation accidents including the recent one in Fukushima, which has yet to exact a fatal toll, but looks certain to in future.

\section{REFERENCES}

Adam, B., Beck, U. and Van Loon, J., (Ed.) (2000). The Risk Society and Beyond: Critical issues for social theory. London: Sage.

Allen, J. and Henry, N. (1997). Ulrich Beck's Risk Society at work: Labour and employment in the contract service industries. Transactions of the Institute of British Geographers, 22(2), 180-196.

Baker, T. and Simon, J. (Ed.). (2002). Embracing Risk: The changing culture of insurance and responsibility. Chicago: University of Chicago Press.

Beck, U. (1992). Risk Society: Towards a new modernity. London: Sage.

Beck, U. (1998). The challenge of world risk society. Korea Journal, 38(1), 196-206.

Beck, U. (1999). World Risk Society. Cambridge: Polity.

Beck, U. (2000). Risk society revisited: Theory, politics and research programmes. Pp. 211-229. In B. Adam, U. Beck, and J. Van Loon (Ed.) London: Sage.

Boholm. A. (2002). The cultural nature of risk: Can there be an anthropology of uncertainty? Ethnos 68(2): 125-143.

Boyne, R. (2003). Risk. Buckingham: Open University Press.

Bradley, W. (2005). Risk Consciousness among Japanese Youth. Pp. 315-334. Journal of the SocioCultural Research Institute, Vol. 5. Otsu, Shiga, Japan: Ryukoku University.

Brinton, M. (2010). Social class and economic life chances in post-industrial Japan: The 'lost generation.’ Pp. 114-133. In H. Ishida and D. Slater (Eds.) Social Class in Contemporary Japan. London: Routledge. 
Caplan, P. (Ed.) (2000). Risk Revisited. London. Pluto Press.

Clammer, J. (2001). Japan and Its Others. Melbourne: Trans Pacific Press.

Crook, S. (1999). Ordering risks. Pp. 160-185. In D. Lupton, (Ed.) Risk and Sociocultural Theory: New Directions and Perspectives. Cambridge: Cambridge University Press.

Douglas, M. (1992). Risk and Blame: Essays in cultural theory. London: Routledge

Ekinsmyth, C. (1999). Professional workers in a risk society. Transactions of the Institute of British Geographers, 24(3), 353-366.

Evans, K., Behrens, M., and Kaluza, J. (2000). Learning and Work in the Risk Society. Houndsmill, Basingstoke, Hampshire: Macmillan.

Furlong, A. and Cartmel, F. (2007). Young People and Social Change: New perspectives, $2^{\text {nd }}$ Ed. Buckingham, PA: Open University Press.

Grew, R. (2002). Comparing modern Japan: Are there more comparisons to make? Online. Available at http://web.mit.edu/newglobalhistory/docs/grew-comparing-modern-japan.pdf (Accessed August 1, 2011).

Lash, S. (2002). Critique of Information. London: Sage.

Lupton, D. (1999). Risk. London: Routledge.

Miyazaki, H. (2010). The temporality of no hope. Pp. 238-250. In C. J. Greenhouse, (Ed.) Ethnographies of Neoliberalism. Philadelphia. PA: University of Pennsylvania Press.

Mythen, G. (2004). Ulrich Beck: A critical introduction to the risk society. London: Pluto Press.

Nugent, S. (2000). Good risk, bad risk: Reflexive modernisation and Amazonia. Pp. 226-248. In P. Caplan, (Ed.).

Oe. K. (1994) Japan, the Ambigous, and Myself. Nobel Lecture 1994. Available http://nobelprize.org/ nobel_prizes/literature/laureates/1994/oe-lecture.html Accessed August 1, 2011

Oe, K. (2011) History Repeats. The New Yorker. March 28, 2011. Available http://www.newyorker. Om/talk/2011/03/28/110328ta_talk_oe Accessed August 1, 2011.

Powell, J. and Edwards, M. (2003). Risk and youth: A sociological narrative. International Journal of Sociology and Social Policy, 23(1): 81-94.

Pyle, K.B. (1996). The Japanese Question: Power and purpose in a new era, $2^{\text {nd }}$ Ed. Washington, D.C.: AEI Press.

Quicke, J. 2001. Curriculum and education for democracy in the risk society. Journal of Curriculum Studies, 33(1): 113-127.

Robertson, S.L. (1999). 'Risky business': Market provision, community, governance and the individualisation of 'risk' in New Zealand education. International Studies in Sociology, 9(2): 171-191.

Semali, L.M. (2000). Literacy in Multimedia America: Integrating media education across the curriculum. New York: Falmer Press.

Strydom. P. (2002). Risk, Environment and Society: Ongoing debates, current issues and future prospects. Buckingham: Open University Press.

Takayama, K. (2007). A Nation at Risk Crosses the Pacific: Transnational borrowing of the U.S. crisis discourse in the debate on education reform in Japan. Comparative Education Review, 51(4): 423-446.

Tamamoto, M. (1999). The uncertainty of the self: Japan at century's end. World Policy Journal 16(2), 119-129.Thiers, P. (2003).

Thiers, P. R. (2004). Risk society comes to China: SARS, transparency and public accountability. Asian Perspectives, 27(2): 241-251.

Tulloch, J. (2008) Culture and risk. Pp. 138-167. In J. Zinn, (Ed.). Social Theories of Uncertainty: An introduction. Malden, MA: Blackwell Publishing.

Tulloch, J. (2004) Risk. In G. Ritzer (Ed.), Handbook of Social Problems: A comparative international perspective. Thousand Oaks, CA: Sage.

Tulloch, J. and Lupton, D. (2003) Risk and Everyday Life. London: Sage.

Van Loon, J. (2002). Risk and Technological Culture: Towards a sociology of virulence. London: Routledge.

Vera-Sanso, P. (2000). Risk-Talk: The politics of risk and its representation. Pp. 108-132. In P. Caplan, (Ed.). 


\section{WILLIAM BRADLEY}

Willis, D., Yamamura, S., and Rappleye, J. (2008). Frontiers of Education: Japan as 'global model' or 'nation at risk'? International Review of Education, 54: 493-515.

Zinn, J. (2008a). (Ed.) Social Theories of Uncertainty: An introduction. Malden, MA: Blackwell Publishing.

Zinn, J. (2008b). A comparison of sociological thinking on risk and uncertainty. Pp. 168-210. In J. Zinn, (Ed.). 